Ophthalmologica 1959;138:320

\title{
Zum 85. Geburtstag von Prof. Dr. J. Meller
}

A.22. Am 22. Oktober dieses Jahres begeht Professor Dr. J. Meller in Wien seinen 85. Geburtstag. Unsere Zeitschrift soil den Tag nicht vorübergehen lassen

ohne der Verdienste dieses bedeutenden Wiener Ophthalmologen für unser Fach und speziell für seine langjährige Redaktionstätigkeit an der «Zeit-schrift für Augenheilkunde» zu gedenken.

Diejenigen unter uns

die mit ihm in dieser Richtung zusammenarbeiten durften werden sich seiner starken Persönlichkeit in Dankbarkeit erinnern. Redaktion und Verlag wünschen dem Jubilar noch víele Jahre der Erhaltung seiner geistigen und physischen Kräfte als Altmeister der Wiener Schule. 